\title{
A comparative morphological study of Viburnum (Adoxaceae) in Korea
}

\author{
Yun Gyeong CHOI and Sang-Hun OH* \\ Department of Biology, Daejeon University, Daejeon 34520, Korea \\ (Received 31 May 2019; Revised 20 June 2019; Accepted 24 June 2019)
}

\begin{abstract}
Viburnum in Korea includes ten species. The phylogenetic relationships and morphology of the genus Viburnum in general have been studied substantially for the past three decades. A clear understanding of the systematic relationships and an assessment of the level of morphological variation of these plants distributed in Korea are lacking. This study investigated the morphology of these species using herbarium specimens and fresh materials obtained during fieldwork to examine the morphological variation level for a better understanding of each species in the genus. A comparative analysis showed that the species of Viburnum in Korea are easily distinguishable based on various characters of the bud, leaf, extrafloral nectary, inflorescence, corolla, fruit, and stone.
\end{abstract}

Keywords: morphology, Viburnum, Adoxaceae, Viburnaceae

The genus Viburnum L. (Adoxaceae) consists of 175-200 species of small trees and shrubs widely distributed in temperate and subtropical regions of Europe, North Africa, Asia, and the Americas (Rehder, 1908; Donoghue, 1983; Hara, 1983; Donoghue et al., 2004). Most of the species are distributed in eastern Asia, eastern North America, and in the mountains of Mexico and South America. Species of Viburnum are easily distinguished from other species in angiosperms by having the growth forms of small trees and shrubs; simple, opposite (rarely whorled) and petiolate leaves; paniculate or umbellate inflorescences, sometimes with marginal sterile flowers; and red to purple black drupes with a single stone (Donoghue et al., 2003). Plants of Viburnum have often been cultivated as ornamentals due to their showy flowers and fragrancy, such as V. opulus L., and V. carlesii Hemsl., and as a medicine source, such as $V$. tinus L. and $V$. erosum Thunb. (Mabberley, 1997; Ahn, 1998; Kwon et al., 2003).

Established by Linnaeus (1753), Viburnum was initially classified in Caprifoliaceae (Jussieu, 1789) and later separated into its own family, Viburnaceae (Rafinesque, 1820). The Angiosperm Phylogeny Group (APG) system recognizes that Viburnum is a member of Adoxaceae together with Sambucus L. (Angiosperm Phylogeny Group, 2016) based on phylogenetic analyses of Dipsacales, in which Viburnum forms a strongly supported clade with Adoxa, Sinoadoxa, Tetradoxa (the three traditional members of Adoxaceae), and Sambucus (e.g., Bell et al., 2001).

The correct family name for Viburnum is complex. Reveal (2008) simultaneously made three proposals for the family name of Viburnum. The first of his proposals (proposal number 1800) recommended the conserving of Viburnaceae owing to Tinaceae, based on the genus Tinus, a synonym of Viburnum. The publication date of Tinaceae is August of 1820 (Reveal, 2008), one month earlier than the publication date of Viburnaceae. This proposal was recommended at the Nomenclature Committee for Vascular Plants (Applequist, 2013). Due to the conservation of Viburnaceae, it is difficult to apply the family name for the clade, which consists of Viburnum, Sambucus and Adoxaceae. When Viburnum and Sambucus are united with Adoxaceae, Viburnaceae has priority over Adoxaceae, an existing conserved name published in 1839 , which would result in the merging of Adoxaceae into Viburnaceae. His second proposal is a "superconservation" of Adoxaceae when Viburnaceae is united with Adoxaceae and Sambucus. This proposal was neither recommended nor rejected by the Specialist Committee, unfortunately (Turland et al., 2018). His third simultaneous proposal is to use the alternative family name Sambucaceae when Adoxaceae, Viburnum, and Sambucus are united. This proposal was neither recommended nor rejected by the Specialist Committee

\footnotetext{
*Author for correspondence: soh42@dju.kr
} 
(Turland et al., 2018). Thus, the correct name would be Viburnaceae when a single family is recognized. We believe that this is unfavorable. No botanical study has ever recognized Viburnaceae as including Adoxaceae and Sambucus. We use Adoxaceae in this paper, following the APG system (Angiosperm Phylogeny Group, 2016).

Various sectional classification systems within Viburnum have been suggested by different authors. The most widely accepted is by Oersted (1861) and Hara (1983), with ten sections recognized (Solenotinus, Viburnum, Pseudotinus, Tomentosa, Tinus, Megalotinus, Lentago, Oreinotinus, Odontotinus, Opulus) based on morphological characters such as bud scales, leaf margins, and the types of inflorescence.

Viburnum received much attention in morphological and evolutionary studies. Egolf (1962) and Zhang et al. (2016) examined chromosome numbers and conducted cytological analyses. Jacobs et al. (2008) investigated seed anatomy and more recently Spriggs et al. (2018) examined leaf form evolutionary processes among species. Hara (1983) in his revision of Caprifoliaceae and Adoxaceae included morphological studies of Viburnum providing taxonomic treatment of the genus for the Japanese species.

Phylogenetic relationships of the sections within Viburnum have been extensively studied based on morphology and molecular data (Donoghue, 1983; Donoghue et al., 2004; Winkworth and Donoghue 2004, 2005; Clement and Donoghue 2011, 2012; Clement et al., 2014). These studies have shown that most sections within Viburnum (Hara, 1963) were supported as monophyletic (Donoghue et al., 2004; Winkworth and Donoghue 2004, 2005; Clement and Donoghue 2011, 2012; Clement et al., 2014). In addition to the traditional classification system, Clement et al. (2014) proposed a phylogenetic classification (Cantino et al., 2007) providing names for strongly supported clades within Viburnum.

There are ten species known in Korea (Hong and Im, 2003; Kim, 2007). Viburnum erosum, V. dilatatum Thunb., V. wrightii Miq., $V$. opulus, and $V$. carlesii var. calvescens are common in the thickets of forests. Viburnum koreanum is rare in Korea, found at high elevations on Seoraksan Mt., and V. furcatum is distributed on Jejudo and Ulleungdo Islands. The occurrence of $V$. furcatum on Jabyeongsan Mt. in Gangwon-do was reported (Son et al., 2008). The evergreen species $V$.japonicum (Thunb. in Murray) Sprengel and $V$. odoratissimum var. awabuki (K. Koch) Zabel ex Rümpler are restricted to Gageodo Island and Jejudo Island, respectively. Viburnum burejaeticum Regel \& Herder is mainly distributed in northern Korea and is designated as an endangered species of Korea by the Ministry of the Environment.
This study aims to examine the morphological characters across the Korean species of Viburnum and determine the level of variation for a better understanding of the phylogenetic relationships and to clarify the taxonomic identity of each species.

\section{Materials and Methods}

In this study, we included ten taxa of Viburnum distributed in Korea. Specimens were collected from the wild in Korea, China, and Japan during the study in 2017 and 2018 and others borrowed from the Herbarium of Vascular Plants at the National Institute of Biological Resources (KB) were used. Specimens collected during this study are deposited at the Daejeon University herbarium (TUT). Approximately 250 specimens were investigated (Appendix 1). Morphological characters such as the habit, bud scale, trichome on branchlets, leaf shape and distribution of the trichome, inflorescence type, corolla shape, fruit color, and stone were examined from the materials. A stereoscopic microscope was used to examine the internal structures of the flowers and trichomes and the characteristics of the stones.

\section{Results}

The species of Viburnum in Korea can be distinguished by several morphological characters, such as the habit, buds, vestiture, leaf size and shape, stipules, extrafloral nectaries, inflorescences, corolla, fruit color, and stone shape.

\section{Habit}

All of the Korean Viburnum species are shrubs. The distinctive feature of two species, $V$. japonicum and $V$. odoratissimum var. awabuki, is that they are evergreen woody plants. All other Korean species are deciduous.
A

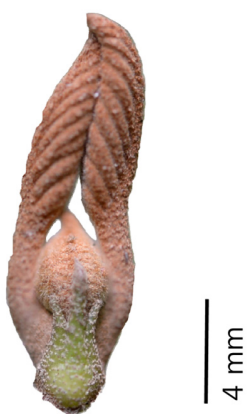

B

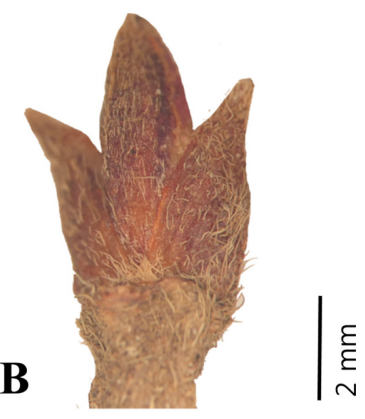

Fig. 1. Buds found in Viburnum in Korea. A. Naked bud without scales. A pair of young leaves which would extend in the next spring is exposed. B. Scaled bud with two pairs of scales. 


\section{Bud}

The buds are located at the apex or the axils of the branchlets and form in summer, lasting until the next spring. There are two types of buds associated with scales: naked buds and scaled buds (Fig. 1). Naked buds do not have scales and expand their outer organs into the leaves (Fig. 1A). Naked buds are found in $V$. burejaeticum, $V$. carlesii, and $V$. furcatum. In most of the species in Korea, buds are enclosed by two or three pairs of scales that fall off as the shoot expands in spring (Fig. 1B). Viburnum burejaeticum and $V$. carlesii are closely related, forming a clade according to a phylogenetic analysis (Clement et al., 2014; Choi et al., 2018) and placed in sect. Viburnum (Hara, 1983). In V. furcatum, a pair of minute caducous scales can be seen in summer, but the bud scales are absent in late fall and winter. The phylogenetic relationships associated with $V$. furcatum are unclear, with classification into sect. Pseudotinus. Clement et al. (2014) suggested that the naked bud may be an ancestral trait in Viburnum and that evolution of the scaled bud from the naked bud may have occurred three times independently within the genus.

\section{Vestiture}

There are two types of non-glandular trichomes in the Korean Viburnum: simple and stellate trichomes. Types of trichomes are useful to distinguish the species in Korea (Table 1). Stellate trichomes densely cover branchlets, petioles, and the adaxial and abaxial surfaces of leaves in $V$. burejaeticum, $V$. carlesii, and $V$. furcatum, all of which have naked buds, as stated previously. In some species, two types of trichomes occur together. Stellate trichomes and simple hairs are found in branchlets, bud scales, petioles, and both surfaces of the leaves in $V$. erosum at a high density. In $V$. dilatatum, both stellate and simple hairs are densely distributed in branchlets and petioles, and only simple hairs are found in bud scales and on both surfaces of the leaves. Bud scales, petioles, and leaves in some plants in $V$. wrightii are sparsely pubescent with simple hairs, and those in other plants are glabrous. Petioles and both surfaces of the leaves in $V$. koreanum and $V$. opulus var. calvescens are glabrous or are sparsely pubescent with simple hairs. Plants of $V$. japonicum are glabrous, and those of $V$. odoratissimum var. awabuki are nearly so, except that the bud scales of the latter are sparsely pubescent with stellate trichomes.

\section{Leaves}

Like other members of Viburnum, the Korean species has simple, opposite leaves. The distribution of stipules varies across the species (Table 2). A pair of stipules 3-7 mm long can be found in $V$. erosum, $V$. koreanum, and $V$. opulus var. calvescens. All other species in Korea are estipulate. Leaves of $V$. koreanum and $V$. opulus var. calvescens are shallowly three-lobed, and those of other species in Korea are unlobed. Viburnum erosum var. taquetii is recognized by having deeply incised leaves with two short lobes (Hara, 1983). Plants with this type of leaf are usually small and also bear unlobed leaves.

Various leaf shapes are found in the Korean Viburnum, such as rounded, ovate, elliptic, obovate, and oblanceolate (Fig. 2, Table 2). Ovate and elliptic leaves are most commonly found in all species in Korea. There is a wide range of variation within the species, and even within a single plant. It is difficult to distinguish the species clearly based on the leaf shape. The

Table 1. Distribution of trichomes in Viburnum.

\begin{tabular}{|c|c|c|c|c|c|}
\hline \multirow{2}{*}{ Species } & \multirow{2}{*}{ Branchlet } & \multirow{2}{*}{ Bud scale } & \multirow{2}{*}{ Petiole } & \multicolumn{2}{|c|}{ Leaves } \\
\hline & & & & Adaxial surface & Abaxial surface \\
\hline V. burejaeticum & Stellate, ++ & - & Stellate, ++ & Stellate, ++ & Stellate, ++ \\
\hline V. carlesii & Stellate, ++ & - & Stellate, ++ & Stellate, ++ & Stellate, ++ \\
\hline V. dilatatum & Stellate \& simple, ++ & Simple, ++ & Stellate \& simple, ++ & Simple, + & Simple, + \\
\hline V. erosum & Stellate \& simple, ++ & Stellate \& simple, ++ & Stellate \& simple, ++ & Stellate \& simple, ++ & Stellate \& simple, ++ \\
\hline$V$. wrightii & Glabrous & Simple, + ; glabrous & Simple, +; glabrous & Simple, +; glabrous & Simple, + ; glabrous \\
\hline V. japonicum & Glabrous & Glabrous & Glabrous & Glabrous & Glabrous \\
\hline V. koreanum & Glabrous & Glabrous & Simple, + ; glabrous & Simple, + ; glabrous & Simple, + ; glabrous \\
\hline $\begin{array}{l}\text { V. opulus } \\
\quad \text { var. calvescens }\end{array}$ & Glabrous & Glabrous & Simple, +; glabrous & Simple, +; glabrous & Simple, + ; glabrous \\
\hline V. furcatum & Stellate, ++ & - & Stellate, + & Stellate, + & Stellate, + \\
\hline $\begin{array}{l}\text { V. odoratissimum } \\
\text { var. awabuki }\end{array}$ & Glabrous & Stellate, + & Glabrous & Glabrous & Glabrous \\
\hline
\end{tabular}


Table 2. Comparison of key morphological character of Viburnum in Korea.

\begin{tabular}{|c|c|c|c|c|c|c|c|c|c|}
\hline \multirow[b]{2}{*}{ Species } & \multirow{2}{*}{$\begin{array}{l}\text { Bud } \\
\text { scale }\end{array}$} & \multirow[b]{2}{*}{ Stipule } & \multicolumn{7}{|c|}{ Leaves } \\
\hline & & & $\begin{array}{l}\text { Petiole length } \\
\text { (cm) }\end{array}$ & Shape & $\begin{array}{l}\text { Length } \\
(\mathrm{cm})\end{array}$ & $\begin{array}{l}\text { Width } \\
(\mathrm{cm})\end{array}$ & Apex & Base & Margin \\
\hline V. burejaeticum & Naked & Absent & $0.5-1.5$ & Ovate, elliptic & $3.6-8.9$ & $2.1-4.8$ & $\begin{array}{l}\text { Acute, } \\
\text { obtuse }\end{array}$ & $\begin{array}{l}\text { Obtuse, } \\
\text { rounded }\end{array}$ & Serrulate \\
\hline V. carlesii & Naked & Absent & $0.3-0.7$ & $\begin{array}{l}\text { Ovate, elliptic, } \\
\text { rounded }\end{array}$ & $2.5-10.0$ & $2.0-7.0$ & $\begin{array}{l}\text { Acute, } \\
\text { rounded }\end{array}$ & $\begin{array}{l}\text { Obtuse, } \\
\text { cordate, } \\
\text { rounded }\end{array}$ & Serrate \\
\hline V. dilatatum & Scaled & Absent & $0.3-1.6$ & $\begin{array}{c}\text { Ovate, elliptic, } \\
\text { obovate }\end{array}$ & $4.5-15.0$ & $2.1-9.2$ & $\begin{array}{l}\text { Acute, } \\
\text { obtuse }\end{array}$ & $\begin{array}{l}\text { Cuneate, } \\
\text { rounded }\end{array}$ & Serrate \\
\hline V. erosum & Scaled & Present & $0.2-0.6$ & $\begin{array}{l}\text { Ovate, elliptic, } \\
\text { obovate }\end{array}$ & $4.6-9.2$ & $1.8-5.0$ & $\begin{array}{l}\text { Acute, } \\
\text { obtuse }\end{array}$ & $\begin{array}{l}\text { Cuneate, } \\
\text { rounded }\end{array}$ & Serrate \\
\hline V. wrightii & Scaled & Absent & $0.8-1.3$ & $\begin{array}{l}\text { Ovate, elliptic, } \\
\text { obovate }\end{array}$ & $5.4-11.0$ & $4.2-8.7$ & $\begin{array}{l}\text { Acute, } \\
\text { obtuse }\end{array}$ & $\begin{array}{l}\text { Cuneate, } \\
\text { rounded }\end{array}$ & Serrate \\
\hline V. japonicum & Scaled & Absent & $1.6-3.1$ & $\begin{array}{l}\text { Ovate, elliptic, } \\
\text { rhombic }\end{array}$ & $5.6-13.6$ & $3.6-10.0$ & $\begin{array}{l}\text { Acute, } \\
\text { obtuse }\end{array}$ & $\begin{array}{l}\text { Cuneate, } \\
\text { rounded }\end{array}$ & Serrate \\
\hline V. koreanum & Scaled & Present & $0.4-2.0$ & $\begin{array}{l}\text { Ovate, elliptic, } \\
\text { suborbicular with } \\
\text { 3-lobes }\end{array}$ & $5.0-8.1$ & $4.2-7.8$ & $\begin{array}{c}\text { Acute, } \\
\text { acuminate }\end{array}$ & $\begin{array}{l}\text { Cordate, } \\
\text { rounded }\end{array}$ & $\begin{array}{c}\text { Irregularly } \\
\text { serrate }\end{array}$ \\
\hline $\begin{array}{l}\text { V. opulus } \\
\text { var. calvescens }\end{array}$ & Scaled & Present & $1.4-3.7$ & $\begin{array}{l}\text { Ovate, elliptic, } \\
\text { suborbicular with } \\
\text { 3-lobes }\end{array}$ & $3.5-11.2$ & $3.4-12.9$ & $\begin{array}{c}\text { Acute, } \\
\text { acuminate }\end{array}$ & $\begin{array}{l}\text { Cordate, } \\
\text { rounded }\end{array}$ & $\begin{array}{c}\text { Irregularly } \\
\text { serrate }\end{array}$ \\
\hline V. furcatum & $\begin{array}{c}\text { Scaled/ } \\
\text { naked }\end{array}$ & Absent & $1.7-3.3$ & Ovate, rounded & $7.5-11.1$ & $5.9-9.7$ & $\begin{array}{l}\text { Acuminate, } \\
\text { rounded }\end{array}$ & $\begin{array}{l}\text { Cordate, } \\
\text { rounded }\end{array}$ & $\begin{array}{c}\text { Irregularly } \\
\text { serrate }\end{array}$ \\
\hline $\begin{array}{l}\text { V. odoratissimum } \\
\text { var. awabuki }\end{array}$ & Scaled & Absent & $1.5-3.3$ & $\begin{array}{c}\text { Elliptic, broadly } \\
\text { elliptic, } \\
\text { oblanceolate }\end{array}$ & $6.0-16.2$ & $2.8-8.0$ & $\begin{array}{l}\text { Acute, } \\
\text { obtuse }\end{array}$ & Cuneate & Entire \\
\hline
\end{tabular}

Table 2. (Continued.)

\begin{tabular}{|c|c|c|c|c|c|c|c|c|c|}
\hline \multirow[b]{2}{*}{ Species } & \multirow[b]{2}{*}{$\begin{array}{c}\text { Extrafloral } \\
\text { nectary }\end{array}$} & \multirow[b]{2}{*}{ Inforescence } & \multirow[b]{2}{*}{$\begin{array}{c}\text { Marginal } \\
\text { sterile flower }\end{array}$} & \multicolumn{2}{|c|}{ Corolla } & \multirow[b]{2}{*}{ Anther color } & \multirow[b]{2}{*}{$\begin{array}{l}\text { Fruit color } \\
\text { in maturity }\end{array}$} & \multicolumn{2}{|c|}{ Stone } \\
\hline & & & & Shape & $\begin{array}{l}\text { Tube } \\
\text { length } \\
(\mathrm{mm})\end{array}$ & & & Shape & $\begin{array}{l}\text { No. of groove } \\
\quad \text { (dorsal, } \\
\text { ventral side) }\end{array}$ \\
\hline V. burejaeticum & Absent & Umbel & Absent & Rotate & $<1$ & Yellow & Black & Ellipsoid & 2,3 \\
\hline V. carlesii & Absent & Umbel & Absent & Tubular & $8-13$ & Yellow & Black & Ellipsoid & 2,3 \\
\hline V. dilatatum & Laminar & Umbel & Absent & Rotate & $<1$ & Yellow & Red & Ovoid & 2,3 \\
\hline V. erosum & Laminar & Umbel & Absent & Rotate & $<1$ & Yellow & Red & Ovoid & 2,3 \\
\hline V. wrightii & Laminar & Umbel & Absent & Rotate & $<1$ & Yellow & Red & Ovoid & 2,3 \\
\hline V. japonicum & Laminar & Umbel & Absent & Rotate & $<1$ & Yellow & Red & Ovoid & 2,3 \\
\hline V. koreanum & Petiolar & Umbel & Absent & Rotate & $<1$ & Yellow & Red & Ovoid-ellipsoid & 2,1 \\
\hline $\begin{array}{l}\text { V. opulus } \\
\text { var. calvescens }\end{array}$ & Petiolar & Umbel & Present & Rotate & $<1$ & Dark purple & Red & $\begin{array}{l}\text { Ovoid-ellipsoid, } \\
\text { cordate }\end{array}$ & 0,0 \\
\hline V. furcatum & Absent & Umbel & Present & Rotate & $<1$ & $\begin{array}{l}\text { Yellow to red, } \\
\text { becoming dark } \\
\text { purple }\end{array}$ & Black & Ovoid-ellipsoid & 1,1 \\
\hline $\begin{array}{l}\text { V. odoratissimum } \\
\text { var. awabuki }\end{array}$ & Absent & Panicle & Absent & Tubular & $3-4.2$ & Yellow & Black & $\begin{array}{l}\text { Ellipsoid, } \\
\text { rhombic }\end{array}$ & 0,1 \\
\hline
\end{tabular}




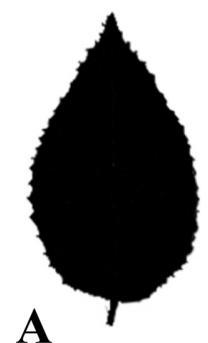

A

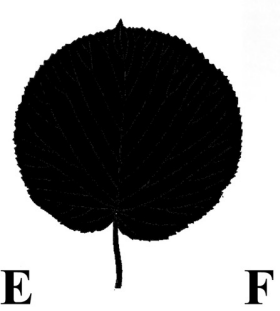

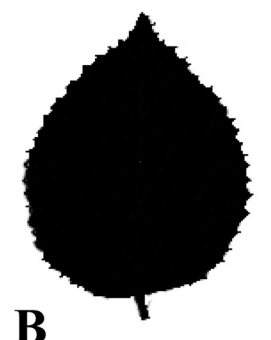

C

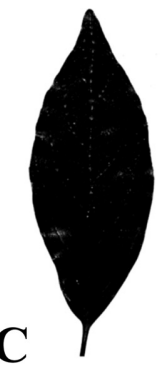

$\mathbf{D}$

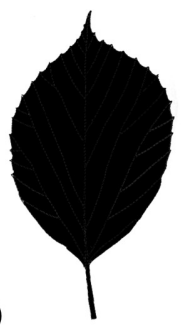

$\mathbf{H}$
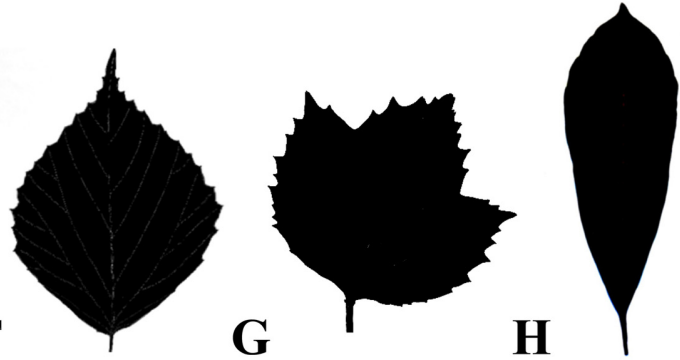

Fig. 2. Leaf shapes of Viburnum in Korea. A. Ovate. B. Broadly ovate. C. Elliptic. D. Obovate. E. Rounded. F. Rhombic. G. Suborbicular with three lobes. H. Oblanceolate. Distribution of the types can be found in Table 2.

A

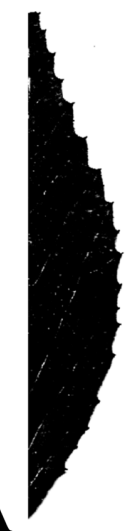

B

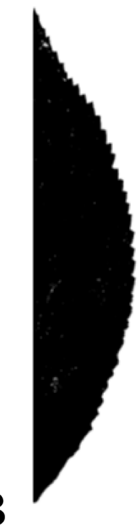

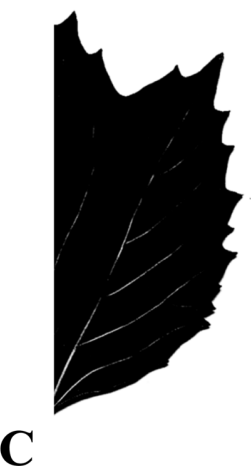

D

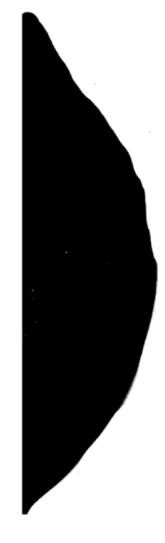

Fig. 3. Leaf margins of Viburnum in Korea. A. Serrate. B. Serrulate. C. Irregularly serrate. D. Entire. Distribution of the types can be found in Table 2.

apices of the species in Korea are acute, acuminate, obtuse, and rounded. Leaves with acute or obtuse apices are common and occur in $V$. burejaeticum, $V$. erosum, $V$. dilatatum, $V$. wrightii, $V$. japonicum, and $V$. odoratissimum var. awabuki. Leaves with acute to acuminate apices are found in $V$. koreanum and $V$. opulus var. calvescens. Leaves with acute or rounded apices are found in $V$. carlesii. Leaves of $V$. furcatum have rounded or acuminate apices. Members of the Korean Viburnum have cordate, rounded, obtuse, or cuneate leaf bases (Table 2). A cuneate or rounded leaf base is found in $V$. dilatatum, $V$. erosum var. erosum, $V$. japonicum, and $V$. wrightii and a cordate or rounded leaf base can be found in $V$. carlesii, $V$. opulus var. calvescens, $V$. koreanum, and $V$. furcatum.
Cuneate leaf base can be found in $V$. odoratissimum var. awabuki. Leaves of $V$. burejaeticum have obtuse or rounded bases and those of $V$. carlesii have obtuse, rounded, or cordate bases. Leaf margins of the Korean Viburnum species are serrate or serrulate, except for $V$. odoratissimum var. awabuki, which has an entire margin (Fig. 3, Table 2).

\section{Extrafloral nectary}

The presence of an extrafloral nectary is an important character within Viburnum. Extrafloral nectaries are found on the upper petiole and on the base of the abaxial surfaces of the leaves in the Korean species (Fig. 4A, B). An extrafloral nectary is absent in $V$. burejaeticum, $V$. carlesii, $V$. furcatum, 


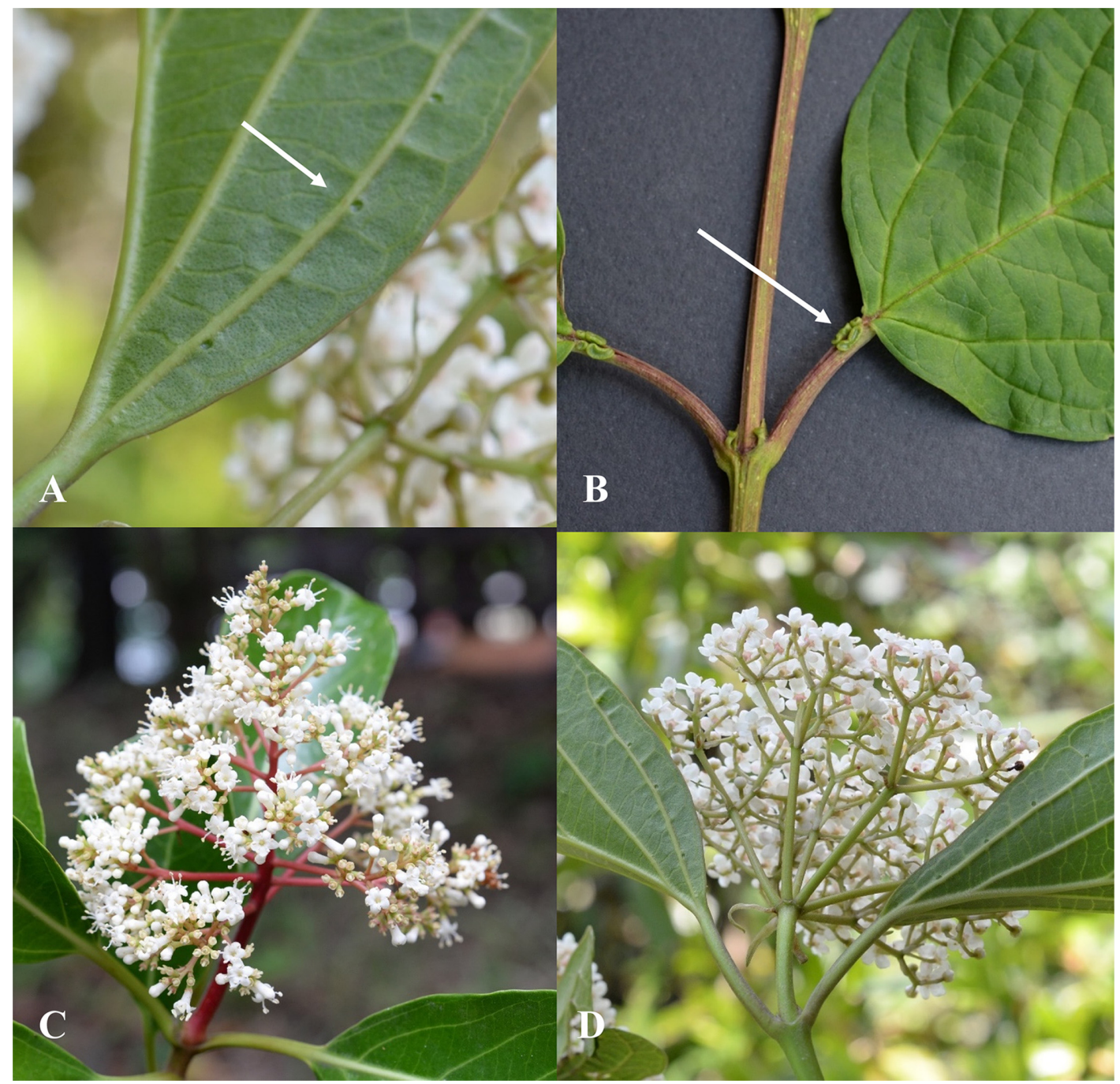

Fig. 4. Extrafloral nectary (A, B) and inflorescene (C, D) found in the species of Viburnum in Korea. A. Laminar nectary. B. Petiolar nectary. The arrow indicates an extrafloral nectary. C. Paniculate inflorescence. D. Umbellate inflorescence. Distribution of the types can be found in Table 2.

and $V$. odoratissimum var. awabuki. A petiolar extrafloral nectary is found in $V$. koreanum and $V$. opulus var. calvescens, and a laminar extrafloral nectary exists in $V$. dilatatum, $V$. erosum var. erosum, $V$. japonicum, and $V$. wrightii. Clement et al. (2014) showed that each type of extrafloral nectary evolved once within Viburnum. It is hypothesized that an extrafloral nectary is associated with mite-containing domatia, which are mutually beneficial to plants and mites (Romero and Benson, 2005).

\section{Inflorescence}

Two different types of inflorescence can be found in the Korean species of Viburnum (Fig. 4C, D, Table 2). Paniculate inflorescences are found in $V$. odoratissimum var. awabuki. Umbellate inflorescences are found in the remaining species of Viburnum. The umbellate inflorescence in Viburnum exists in a compound form in which the cymes branch from a single point, resembling a compound umbel. Umbellate inflorescences are most common in Viburnum, as a paniculate inflorescence is only found in the Solenotinus clade (Clement et al., 2014). Viburnum clemensiae, a sister to the remaining species of Viburnum has paniculate inflorescences. Paniculate inflorescences in these lineages were independently derived from umbellate inflorescences (Clement and Donoghue, 2011). Paniculate inflorescences consist of lateral branches of cymes along the main axis, being panicles of cymes. Hara (1983) postulated that the umbellate inflorescence was derived from the paniculate inflorescence by means of the evolutionary condensation of internodes of the main axis. A phylogenetic analysis of Viburnum (Clement and Donoghue, 

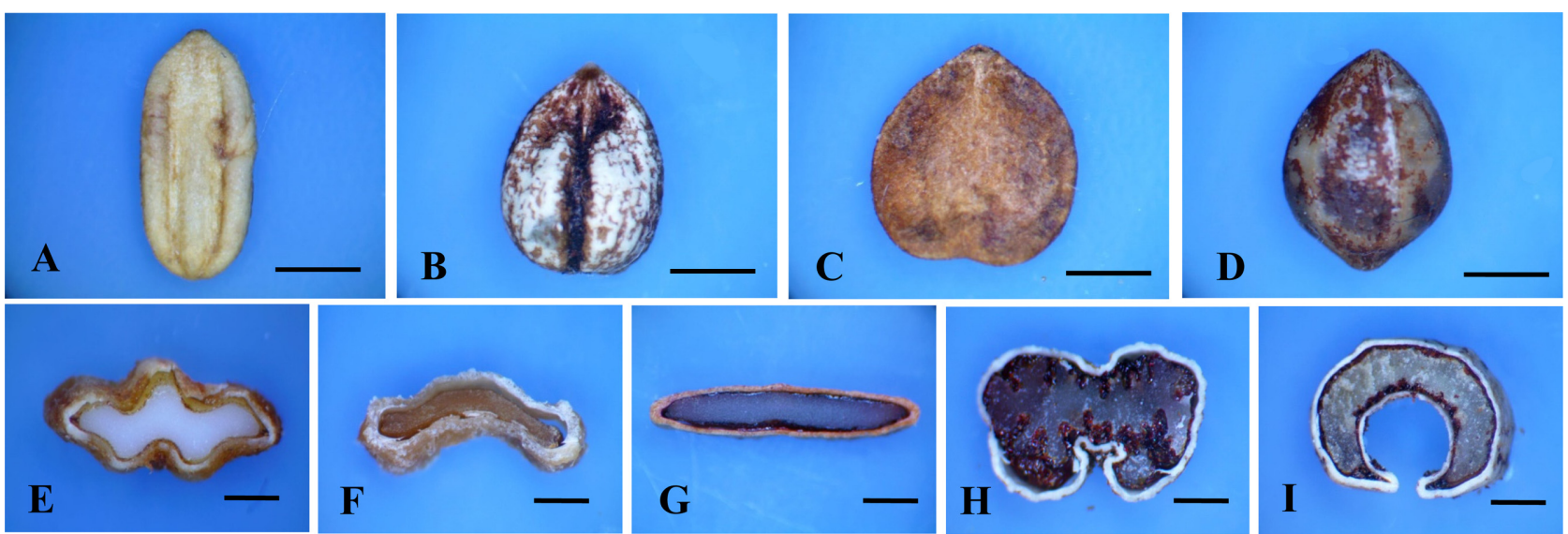

Fig. 5. Microscopic photographs of stones found in the species of Viburnum Korea. A-D. Overall shape of the stones. E-I. Cross-section of the stones. A. Ellipsoid. B. Ovoid. C. Cordate. D. Rhombic. E. Two dorsal (upper side in the photograph) and three ventral grooves. F. Two dorsal grooves and one ventral groove. G. Flat, without grooves on both sides. H. One dorsal and one ventral groove. I. One groove only on the ventral side. Scale bars: A-D $=2.5 \mathrm{~mm}, \mathrm{E}-\mathrm{I}=1 \mathrm{~mm}$.

2011), however, suggested that paniculate inflorescences evolved from an umbellate form by elongation of the primary axis.

Marginal sterile flowers occur in $V$. opulus var. calvescens and $V$. furcatum. The corolla lobes of the marginal flowers are three to five times longer than the corolla lobes of fertile regular flowers in the same inflorescence. All other species have only fertile flowers in an inflorescence.

\section{Flower}

Regular flowers of Viburnum are bisexual and actinomorphic. The corolla is rotate or tubular (Table 2). A tubular corolla is found in $V$. carlesii and $V$. odoratisimum var. awabuki and rotate corollas can be found in all other remaining species in Korea. Members of the Korean Viburnum have five stamens alternate to corolla lobes. Stamens are exerted in all species in Korea, except for $V$. carlesii, in which the stamens are included in the corolla tube. The length of the filaments in $V$. carlesii is the longest among the Korean members, in a range of 7-10 mm, whereas the filaments in the other species are 3$4 \mathrm{~mm}$ long. The anther color varies across the species in Korea (Table 2). Yellow anthers are common in the Korean members of Viburnum. Purple anthers are found in $V$. opulus var. calvescens. Anthers of $V$. furcatum are initially yellow to red but become dark purple.

\section{Fruit}

The fruits in all species of Viburnum are drupes containing a one-seeded stone. Fruits are red or black in maturity depending on the species (Table 2). Initially, the fruits in all species of the Korean Viburnum are red in color, but those in
V. burejaeticum, V. carlesii, V. furcatum, and V. odoratissimum var. awabuki turn black when mature.

The stone shape and the number of grooves have been used to distinguish the species within Viburnum (Hara, 1983). Among the Korean members of Viburnum, ellipsoid and ovoid shapes and their derivatives or intermediate forms can be found (Fig. 5, Table 2). The number of grooves on the stone is a clear phylogenetic signal and can be examined by the cross-section of the stone (Fig. 5). The cross-section of the stone in V. opulus var. calvescens is flat and with no groove on either side. Stones of $V$. odoratissimum var. awabuki have one groove on the ventral side only, and those of $V$. furcatum have one groove each on the dorsal and ventral sides. Two dorsal and one ventral grooves are found in the stones of $V$. koreanum. The type with two dorsal and three ventral grooves is most common in the Korean Viburnum, occurring in six species ( $V$. burejaeticum, $V$. carlesii, $V$. dilatatum, $V$. erosum var. erosum, $V$. japonicum, and $V$. wrightii). The shapes of the cross-section of the stones can vary (Fig. 5).

\section{Discussion}

This study reviews the morphological characteristics of Viburnum in Korea, including V.japonicum, which is reported as being from Gageodo Island (Hong and Im, 2003). Despite the misconception that species of Viburnum may lack morphological features, various characters in the bud, leaf, extrafloral nectary, inflorescence, corolla, fruit, and stone are useful to distinguish the species and infer relationships.

Viburnum odoratissimum var. awabuki is most distinctive species in Korea by having evergreen leaves with an entire 
1. Plants evergreen.

2. Inflorescence paniculate V. odoratissimum var. awabuki

2. Inflorescence umbellate V. japonicum

1. Plants deciduous.

3. Winter buds naked or enclosed by a pair of caducous scales; leaves without extrafloral nectaries; drupes initially red, black at maturity; stones not compressed, deeply grooved.

4. Buds with a pair of caducous scales becoming naked in winter; inflorescences subsessile; large marginal sterile flowers present; stones with 1 dorsal and 1 ventral grooves V. furcatum

4. Buds naked from beginning; inflorescences pedunculate; all flowers fertile; stones with 2 dorsal and 3 ventral grooves.

5. Corolla rotate white; stamens exserted V. burejaeticum

5. Corolla tubular, pale pink; stamens included V. carlesii

3. Winter buds enclosed by 2 or 3 pairs of scales; leaves with extrafloral nectaries on petioles or on abaxial surface; drupes red at maturity; stones compressed, shallowly grooved.

6. Leaves 3-5-lobed, palmately 3-5-veined, extrafloral nectaries present on petioles.

7. Marginal flowers in inflorescences sterile ………………........................................... V. opulus var. calvescens

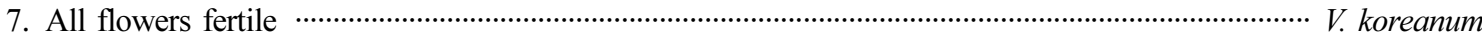

6. Leaves serrate, pinnately veined, extrafloral nectaries present at base on abaxial surface.

8. Stipules present …............................................................................................................... V V erosum

8. Stipules absent.

9. Branchlets glabrous; petioles glabrous or sparsely pubescent with simple hairs …........................ $V$. wrightii

9. Branchelets and petioles densely pubescent with simple and stellate hairs ……............................ $V$. dilatatum

Fig. 6. A key to the species of Viburnum in Korea

margin and paniculate inflorescences (Table 2). It is classified in the sect. Solenotinus (Rehder, 1908; Hara, 1983). Members of the section have a basic chromosome number of $x=8$, paniculate inflorescences, and one deep longitudinal groove on the ventral side. Viburnum odoratissimum var. awabuki is found on Jejudo Island in Korea and in Japan, Taiwan, and the Philippines. Plants with thin, widely obovate leaves with four to six lateral veins, and green petiole and sub-rotate corollas with a tube less than $2 \mathrm{~mm}$ long are considered as $V$. odoratissimum var. odoratissimum (Hara, 1983), which is distributed in Assam, Myanmar, northeastern Thailand, and western and central China.

Viburnum furcatum is easily distinguished from other members of the Korean Viburnum by having a pair of caducous bud scales resulting in naked buds in winter, stellate trichomes, umbellate inflorescences with marginal sterile flowers, and one groove each on both sides of the stones (Tables 1,2). The species belongs to sect. Pseudotinus (Hara, 1983). It is commonly distributed from South Sakhalin to Japan but extends to Korea and then to Taiwan (Hara, 1983; Kim, 2007). Plants of this species are locally common at high elevations on Hallasan Mt. and are rare on Ulleungdo Island. An occurrence of the species at Jabyeongsan Mt. in Gangwon province in Korea was reported (Son et al., 2008), but we did not locate the population.
Viburnum carlesii was originally described from Korea (Incheon and west Korea) (Forbes and Hemsley, 1888) and can be easily distinguished from other members of Korean Viburnum by having tubular corollas in which stamens are included (Table 2 ). It is closely related to $V$. burejaeticum by having densely pubescent with stellate trichomes on the branchlets, petioles, and leaves; naked buds; and stones with two dorsal and three ventral grooves (Tables 1,2). The two species are classified in sect. Viburnum (Hara, 1983) and placed in the Lantana clade (Clement et al., 2014). While $V$. carlesii is common in Korea, it is rare in Japan and China. Viburnum burejaeticum is distributed at high latitudes in Korea, the Russian Far East, and northeastern China, but is rare in Korea. Hara (1983) recognized V. carlesii var. bitchiuense (Makino) Nakai by having ovate or elliptic leaves with an acute apex and a roundish base, loose cymes, a pink corolla tube, and stamens inserted below the middle of the corolla tube with longer free filaments. The characteristics are variable within a population and the two varieties are thus considered as indistinct.

Viburnum koreanum and V. opulus are distinctive by having a petiolar extrafloral nectary (Fig. 4) and shallowly three-lobed leaves. Viburnum opulus is rather common and often planted in gardens and along streets. It is easily distinguished by having 
marginal sterile flowers and an irregularly loose serrate leaf margin. Plants of the two species are usually glabrous, and leaves can be sparsely pubescent with simple hairs. Viburnum koreanum is rare in Korea and is distributed on Seoraksan Mt.

The $V$. dilatatum complex, which consists of four closely related species ( $V$. dilatatum, $V$. erosum, $V$. wrightii, and $V$. japonicum), is characterized by free bud scales and serrate leaves with pinnate veins and extrafloral nectaries at proximal regions on the abaxial surface (Tables 1, 2). Viburnum japonicum can be easily distinguished from the other members of the complex by having evergreen leaves. It is distributed in the warm temperate forests of southern Japan and the Rhukyu archipelago, and disjunctively on Gageodo Island in Korea. Deciduous members of the complex $V$. erosum, found in southern China, Taiwan, southern Japan, and Korea, can easily be distinguished by having stipulate leaves and stellate trichomes together with simple hairs on bud scales and branchlets. Leaf shapes vary greatly, being obovate with a cuneate base, ovate with a rounded base, and deeply incised with two short lateral lobes at the base. Different types of leaves can be found on the same branch. Viburnum dilatatum is widely distributed in Korea, Japan, and China. Bud scales are usually densely pubescent with simple hairs, and branchlets are covered with both stellate and simple hairs. In contrast, plants of $V$. wrightii are glabrous except that the apexes of bud scales, petioles, and leaves may have simple hairs. The leaves of $V$. wrightii tend to be wide compared to those of $V$. dilatatum. There are some plants showing intermediate or aberrant forms in the $V$. dilatatum complex. More detailed studies of the taxonomic nature and origin of these forms are underway.

Based on our morphological study, we here provided a key to the species of Viburnum in Korea (Fig. 6).

ORCID: Yun Gyeong CHOI https://orcid.org/0000-0001-67233923; Sang-Hun OH https://orcid.org/0000-0001-8778-4458

\section{Acknowledgments}

We thank Narae Yun, Seung Hyun Whang, Ji-Hyun Park, Dong-Hyuk Lee, Seon Won Suh, and Hwa-Jung Suh for their help with the fieldwork. We are grateful to the staff of KB who generously provided the specimen loans and to two anonymous reviewers for their constructive comments. This work represents a part of an MS thesis of the first author submitted to Daejeon University. This work was supported by a research grant from the National Research Foundation of Korea, NRF-2016R1D1A1B03934663.

\section{Conflict of Interest}

The authors declare that there are no conflicts of interest.

\section{Literature Cited}

Ahn, D. K. 1998. Illustrated Book of Korean Medicinal Herbs. Kyohaksa, Seoul, 854 pp.

Angiosperm Phylogeny Group. 2016. An update of the Angiosperm Phylogeny Group classification for the orders and families of flowering plants: APG IV. Botanical Journal of the Linnean Society 181: 1-20.

Applequist, W. L. 2013. Report of the Nomenclature Committee for Vascular Plants: 65. Taxon 62: 1315-1326.

Bell, C. D., E. J. Edwards, S.-T. Kim and M. J. Donoghue. 2001. Dipsacales phylogeny based on chloroplast DNA sequences. Harvard Papers in Botany 6: 481-499.

Cantino, P. D., J. A. Doyle, S. W. Graham, W. S. Judd, R. G. Olmstead, D. E. Soltis, P. S. Soltis and M. J. Donoghue. 2007. Towards a phylogenetic nomenclature of Tracheophyta. Taxon 56: 822-846.

Choi Y. G., J. W. Youm, C. E. Lim and S.-H. Oh. 2018. Phylogeneitc analysis of Viburnum (Adoxaceae) in Korea using DNA sequences. Korean Journal of Plant Taxonomy 48: 206-217.

Clement, W. L. and M. J. Donoghue. 2011. Dissolution of Viburnum section Megalotinus (Adoxaceae) of Southeast Asia and its implications for morphological evolution and biogeography. International Journal of Plant Sciences 172: 559-573.

Clement, W. L. and M. J. Donoghue. 2012. Barcoding success as a function of phylogenetic relatedness in Viburnum, a clade of woody angiosperms. BMC Evolutionary Biology 12: 73.

Clement, W. L., M. Arakaki, P. W. Sweeney, E. J. Edwards and M. J. Donoghue. 2014. A chloroplast tree for Viburnum (Adoxaceae) and its implications for phylogenetic classification and character evolution. American Journal of Botany 101: 10291049.

Donoghue, M. J. 1983. The phylogenetic relationships of Viburnum. In Advances in Cladistics, Vol. 2. Platnick, N. I. and V. A. Funk (eds.), Columbia University Press, New York. Pp. 143-166.

Donoghue, M. J., B. G. Baldwin, J. Li and R. C. Winkworth. 2004. Viburnum phylogeny based on chloroplast $\operatorname{trnK}$ intron and nuclear ribosomal ITS DNA sequences. Systematic Botany 29: $188-198$.

Donoghue, M. J., C. D. Bell and R. C. Winkworth. 2003. The evolution of reproductive characters in Dipsacales. International Journal of Plant and Science 164: S453-S464.

Egolf, D. R. 1962. A cytological study of the genus Viburnum. 
Journal of the Arnold Arboretum 43: 132-172.

Felsenstein, J. 1985 Confidence limits on phylogenies: an approach using the bootstrap. Evolution 39: 783-791.

Forbes, F. B. and W. B. Hemsley. 1888. Enumeration of all the plants known from China proper, Formosa, Hainan, the Corea, the Luchu archipelago, and the Island of Hong Kong. Journal of Linnean Society 23: 401-492.

Hara, H. 1983. A Revision of Caprifoliaceae of Japan with Reference to Allied Plants in Other Districts and the Adoxaceae. Academia Scientific Books, Tokyo, 336 pp.

Hong, H.-H. and H.-T. Im. 2003. Viburnum japonicum (Caprifoliaceae): an unrecorded species in Korea. Korean Journal of Plant Taxonomy 33: 271-277.

Jacobs B., M. J. Donoghue, F. Bouman, S. Huysmans and E. Smets. 2008. Evolution and phylogenetic importance of endocarp and seed characters in Viburnum (Adoxaceae). International Journal of Plant Sciences. 169: 409-431.

Jussieu, A. L. de. 1789. Genera Plantarum. Herissant, Paris, 498 pp.

Kim, T. J. 2007. Viburnaceae Raf. In The Genera of Vascular Plants of Korea. Park C.-W. (ed.), Academy Publishing Co., Seoul. Pp. 944-946.

Kwon, M. K., H. E. Lee, J. Y. Park and Y. S. Hahn. 2003. Antimicrobial activities of berry extract of domestic plants on four kinds of pathogenic microorganism. Journal of the East Asian Society of Dietary Life 13: 433-438.

Linnaeus, C. 1753. Species Plantarum. Salvius, Stockholm, 1200 pp. Mabberley, D. J. 1997. The Plant-Book. 2nd ed. Cambridge University Press, Cambridge, 680 pp.

Oersted, A. S. 1861. Til belysning af slaegten Viburnum. Videnskabelige Meddelelser fra Dansk Naturhistorisk Forening i Kjobenhavn 13: 267-305.

Rafinesque, C. S. 1820. Monographie des coquilles bivalves fluviatiles de la rivière Ohio, contenant douze genre et soixantehuit espèces. Annales Générales des Sciences Physiques 5: 287-322.
Reveal, J. L. 2008. (1800-1802) Proposals to conserve the name Viburnaceae (Magnoliophyta), the name Adoxaceae against Viburnaceae, a "superconservation" proposal, and, as an alternative, the name Sambucaeae. Taxon 57: 303.

Rehder, A. 1908. The Viburnums of eastern Asia. In Trees and Shrubs, Vol. II, Part II. Sargent, C. S. (ed.), Houghton Mifflin, Boston, MA. Pp. 105-116.

Romero, G. Q. and W. W. Benson. 2005. Biotic interactions of mites, plants and leaf domatia. Current Opinion in Plant Biology 8: 436-440.

Son, H.-D., D.-H. Kim and H.-T. Im. 2008. A short record for the distribution of 4 rare plants. Korean Journal of Plant Taxonomy 38: 565-571.

Spriggs, E. L., S. B. Schmerler, E. J. Edwards and M. J. Donoghue. 2018. Leaf form evolution in Viburnum parallels variation within individual plants. The American Naturalist 191: 235-249.

Turland, N. J., J. H. Wiersema, F. R. Barrie, W. Greuter, D. L. Hawksworth, P. S. Herendeen, S. Knapp, W.-H. Kusber, D.-Z. Li, K. Marhold, T. W. May, J. Mcneill, A. M. Monro, J. Prado, M. J. Price and G. F. Smith. 2018. International Code of Nomenclature for Algae, Fungi, and Plants (Shenzhen Code) Adopted by the Nineteenth International Botanical Congress Shenzhen, China, July 2017. Regnum Vegetabile 159. Koeltz Botanical Book, Glashütten, 254 pp.

Winkworth, R. C. and M. J. Donoghue. 2004. Viburnum phylogeny: evidence from the duplicated nuclear gene GBSSI. Molecular Phylogenetics and Evolution 33: 109-126.

Winkworth, R. C. and M. J. Donoghue. 2005. Viburnum phylogeny based on combined molecular data: implications for taxonomy and biogeography. American Journal of Botany 92: 653-666.

Zhang, N., W. B. Sun and J. Yang. 2016. Chromosome counts and karyotype analysis of Viburnum taxa (Adoxaceae). Caryologia. 69: 12-19.

Appendix 1. List of specimens examined in this study.

V. burejaeticum: KOREA. Gangwon-do: Pyeongchang-gun, 4 Sep 2016, Suh H. J. 7129 (TUT); 5 May 2017, Lee D. H. 7194 (TUT); 8 May 2012, Kim J. H. et al. KIMJH12048 (KB 356575). CHINA. Jilin, Antu, 4 Jun 2011, Kim J. S. BDS72 (KB 289365 ).

V. Carlesii.: KOREA. Gangwon-do: Hongcheon-gun, 6 May 2004, Yoo K. O. et al. 1306 (KB 277454); Jeongseon-gun, 19 Apr 2016, Nam G. H. Baeki160223 (KB 568269); Pyeongchang-gun, 23 Apr 2016, Kim S. H. \& Oh Y. S. PC02A3034 (KB 577861); Yanggu-gun, 1 May 2008, Yoo K. O. VP KB 3871620143 (KB 154489); Yeongwol-gun, 2 Jun 2010, Hyun J. O. \& Kang S. I. NAPI 20101309 (KB 300036). Gyeonggi-do: Incheon-si, Ongjin-gun, 14 Apr 2007, Hyun J. O. 2007018 (KB 110788);16 Jun 2009, Hyun J. O. et al. NAPI 20100259 (KB 292426); 17 Jun 2009, Hyun J. O. et al. NAPI 20100398 (KB 292954); 22 May 2012, Lee B. C. \& Seo W. B. s.n. (KB 428884). Gyeongsangbuk-do: Andong-si, 24 Apr 2007, Jung K. Y. ANH en 070424003 (KB 121542); Ulleung-gun, Ulleungdo Island, 29 May 2017, Ahn J. G. 7274 (TUT).

V. dilatatum: KOREA. Gyeongsangbuk-do: Sangju-si, 7 Jun 2008, Chung G. Y. \& Park M. S. s.n. (KB 156815); Seongju-gun, 
26 May 2012, Kang S. H. 358021 (KB 445136). Gyeonsangnam-do: Hapchun-gun, 28 May 2007, Ko S. C. \& Kim J. H. s.n. (KB 277245). Jeollabuk-do: Wanju-gun, 14 May 2017, Yun N. R. 7214 (TUT). Jeollanam-do: Yeongam-gun, 19 Oct 2013, Kim M. H. seed3482 (KB 448592). Jeju-do: Aewol-eup, 4 Oct 2013, Moon M. O. \& Kim J. E. 4926 (KB 478461); Jeju-si, Gujwa-eup, 2 Sep 2014, Moon M. O. 5806 (KB 512282); Odeung-dong, 2 Oct 2013, Moon M. O. \& Kim J. E. 4895 (KB 478430).

V. erosum var. erosum: KOREA. Gyeonggi-do: Incheon-si, Ganghwa-gun, 12 May 2015, Na H. R. N EX11 (KB 534161). Chungcheongnam-do: Taean-gun, 21 May 2015, Lee H. S. sulee20151 (KB 545752). Gyeongsangbuk-do: Gunsan-si, 20 May 2017, Hwang S. H. 7219 (TUT); Namwon-si, 2006, Baek W. K. s.n. (KB 278061); Pohang-si, 27 Jul 2005, Kim Y. D. et al. 05171 (KB 277686). Gyeongsangnam-do: Miryang-si, 17 Jun 2013, Hong Y. H. HNHM KB 131654 (KB 531012); Ulsan-si, 7 May 2007, Lee S. M. \& Bak S. S. s.n. (KB). Jeollabuk-do: Imsil-gun, 5 May 2007, Sun B. Y. 1029 (KB 127413); Namwon-si, 2006, Paik W. K. et al. s.n. (KB 278061). Jeollanam-do: Sinan-gun, Hongdo Island, 20 May 2017, Oh S. H. et al. 7224 (TUT). Jeju-do, Jeju-si, Gujwa-eup, 29 Jul 2011, Kim H. J. 110729 JJ253 (KB 577555); Seogwipo-si, Namwon-eup, 15 Jun 2009, Kang C. M. et al. 27315 (KB 257106).

V. furcatum: KOREA. Jeju-do: Jeju-si, Aewol-eup, 27 May 2010, Moon M. O. 339 (KB 291710); 16 Jun 2010, Kim C. H. \& Yoon N. R. 50400 (KB 329347); 11 Sep 2010, Ko S. C. \& Son D. C. HNHM 20101214 (KB 307714); 20 Jul 2011, Ko S. C. et al. HNHM 20010656 (KB 386202); Haean-dong, 26 Sep 2011, Moon M. O. \& Kim J. E. 2509 (KB 368833); Jocheon-eup, 15 Apr 2014, Moon M. O \& Im E. Y. 55431 (KB 511949); Seogwipo-si, Hawon-dong, 22 Jun 2010, Kang C. M. \& Lim J. N. 29854 (KB 317840); 15 May 2017, Oh S. H. et al. 7203 (TUT). JAPAN. Hokkaido: Sapporo Pref., 27 Aug 2017, Oh S. H. et al. 7464 (TUT).

V. japonicum: KOREA. Jeollanam-do: Sinan-gun, Gageodo Island, 2 May 2009, Hyun J. O. et al. s.n. (KB 337387); 21 May 2011, Nam K. H. et al. Gageo118 (KB 289026); 22 May 2011, Nam K. H. et al. Gageo211 (KB 289119); Gageo234 (KB 289142$)$; 13 Jul 2011, Nam G. H. et al. Gageo435 (KB 307885); 24 Oct 2013, Choi H. G. et al. 754 (KB 473764); 25 Oct 2013 , Choi H. K. et al. 893 (KB 474443); 17 May 2017, Lee D. H. 7216 (TUT). JAPAN. Kyushu: Nagasaki Pref., 21 Aug 2018, Hwang S. H. et al. Kyushu-043 (TUT).

V. koreanum: KOREA. Gangwon-do: Inge-gun, 3 Jun 2017, Lee D. H. 7294 (TUT). CHINA. Jilin, Fusong, 5 Aug 2018, Suh H. J. 7589, 7590 (TUT).

V. odoratissimum var. awabuki: KOREA. Gyeongsangnam-do: Geoje-si, 19 Jun 2010, Jeon E. S. 348031 (s0686) 0146 (KB 409268); Jeju-do: Jeju-si, Gujwa-eup, 5 May 2011, Choi B. H. et al. 336083006 (KB 393880); Hangyeong-myeon, 8 Oct 2009 , Kim D. S. seed12 (KB 246520); Seogwipo-si, Andeok-myeon, 21 Mar 2012, Kang S. H. s.n. (KB 434902); Jungmun-dong, 4 Sep 2012, Kang C. M. et al. 36062 (KB 418140);12 Jun 2017, Choi Y. G. 7317 (TUT); Namwon-eup, 5 Sep 2012, Kang C. M. et al. 36118 (KB 418149); Sanghyo-dong, 9 Jul 2010, Kang C. M. \& Hong S. C. 29912 (KB 321129); Seongsan-eup, 13 Jun 2017, Choi Y. G. 7321 (TUT).

V. opulus var. calvescens: KOREA. Gangwon-do: Cherwon-gun, 29 May 05 2017, Hwang S. H. 7275 (TUT); Hongcheon-gun, 9 Jun 2010, Hyun J. O. \& Kwon H. J. NAPI 20101397 (KB 299993); Inge-gun, 30 Jun 2009, Ko S. C. HNHM 0339 (KB 252268 ); Jeongseon-gun, 12 Jun 2009, Im H. T et al. Im0152 (KB 258540); 18 Sep 2009, Im H. T et al. Im0515 (KB 258800); Pyeongchanggun, 9 Jul 2009, Jung J. D. \& Kim C. K. 09072821 (KB 255027); Wonju-si, 14 Jun 2003, Kim K. J. et al. 20030886 (KB 208170); Yanggu-gun, 23 Jun 2008, Yoo K. O. et al. s.n. (KB 154759); Yeongwol-gun, 26 May 2010, Nam K. H. et al. SHY291 (KB 235185). Gyeonggi-do: Incheon-si, 29 May 2017, Oh S. H. et al. 7273 (TUT); Yeoncheon-gun, 3 Jul 2008, Lee J. H et al. 2008480768 (KB 161802); 23 Jul 2008, Kim D. K. \& Hwang S. H. 387131065 (KB 157769); 30 May 2017, Hwang S. H. 7276 (TUT). Chungcheongbuk-do: Danyang-gun, 4 Aug 2009, Ko S. C. et al. HNHM 1135 (KB 253062).

V. wrightii: KOREA. Gangwon-do: Hoengseong-gun, 3 Jun 2008, Ko S. C. 20080009 (KB 198135); Inje-gun, 5 Sep 2009 , Kim H. W. \& Yang S. Y. 20080936 (KB 163578); 28 Aug 2009, Moon M. O. et al. CH41460 (KB 264939); 3 Jun 2010 , Yoo K. O. s.n. (KB 492372); 16 Sep 2013, Han B. W. et al. NAPI S2013086 (KB 458890); Pyeongchang-gun, 30 Jun 2008, Jung G. Y. ANH en 080630104 (KB 197686). Gyeongsangbuk-do: Ulleung-gun, Ulleungdo Island, 16 Sep 2005, Hyun J. O. et al. NAPI 20101239 (KB 293906). Jeollabuk-do: Jeongeup-si, 15 May 2011, Kim C. H. et al. J600415 (KB). Jeju-do: Jeju-si, Aewol-eup, 16 Jun 2010, Kim C. H. et al. J50374 (KB); Gujwa-eup, 4 May 2018, Oh S. H. et al. 7539 (TUT). JAPAN. Kyushu: Saga Pref., 20 Aug 2018, Hwang S. H. et al. Kyushu-003 (TUT). 